土に混和する必要があり, 多大な労力とコストが必要で ある。これに対して石高は溶解度が高く, 速やかな下層 土酸性の改良が可能である。筆者らは, 我が国の主要な 畑土壤である黒ボク土の中で, 酸性の強い非アロフェン 質黒ボク土へのリン酸石亳の施用試験を行ない, 下層土 への速やかな移動, 植物に有害な交換性 $\mathrm{Al}$ の減少, 作 物根の伸長の増加などの効果をもつことを明らかにし た ${ }^{(5)}$. しかし, 石膏による酸性改良効果は土㙵の種類に より異なり,さらに詳細な検討が必要である(6).

近年の有機農業への関心の高まりから, 家畜ふん堆肥 をはじめとする有機物の施用は増加している一方で, 堆 肥その他からの窒素などの流出が懸念されている，石膏 を有機物と混合すると, Ca-有機物複合体を形成するこ とにより安定化すると考えられる，筆者らは，石高の添 加により稲わら堆肥の分解之窒素の無機化のいずれも抑 制されることを明らかにした(7).この有機物の分解抑制 により, 無機化した窒素などの流亡が軽減されると考え られる。

石膏を土㙵に施用した際に，その効果の持続性を明ら かにすることは利用法を確立する上で重要である，米国 ショョージア州において石膏を施用後 16 年が経過した围 場を用いた検討によって, 交換性 $\mathrm{Al}$ の減少, 作物の生 育・収量増加など, 石亮の酸性改良効果が長期間にわ
たって持続することが明らかになっている(8).これらの 他に, アルカリ土㙵の除塩や土壤表面が固結するクラス 卜現象の抑制などに対する石膏の効果についても報告さ れている(1).

石亳は様々な農業利用の可能性をもつ資材である。副 産物石膏の農業利用法の確立は, 資源の有効利用や廃棄 物の適切な処理，さらには中国をはじめとする新興工業 国に扔ける大気污染対策を進める一助になると考えられ る. 今後は, 石膏の利用可能な土壌, 作物を明らかにす るとともに，多施用を行なった際に懸念される $\mathrm{Mg}$ など 他要素との拮抗作用の有無, 各種副産物石膏の品質など も含めさらに検討し, 利用方法を確立していく必要があ る.

1) I. S. Alcordo \& J. E. Rechcigl: "Soil Amendment and Environmental Quality”, ed. by J.E. Rechcigl, CRC Press, Boca Raton, 1995, p. 365.

2) 藤間 充，三枝正彦，渋谷暁一：土肥誌， 66, 264 (1995).

3) 高須栄一, 山田文栄, 嶋田永生, 吉田吉明, 三枝正彦：土 肥誌, 77,1 (2006).

4）藤間 充，三枝正彦，渋谷暁一：日草誌，43, 164 (1997).

5) M. Toma \& M. Saigusa : Plant Soil, 192, 49 (1997).

6) T. Takahashi, Y. Ikeda, H. Nakamura \& M. Nanzyo: Soil Sci. Plant Nutri., 52, 584 (2006).

7) 藤間 充，三枝正彦：土肥誌， 68, 645 (1997).

8) M. Toma, M. E. Sumner, G. Weeks \& M. Saigusa : Soil Sci. Soc. Am. J., 63, 891 (1999).

（藤間 充，山口大学農学部附属農場）

\title{
炭素-炭素結合をタンパク質に導入する 遺伝子工学と有機合成化学の融合
}

タンパク質はリボソームで, tRNA によって運搬され てきたアミノ酸が遺伝子 DNA の転写物である mRNA のコドンに対応して，順々に重合することで生合成され る. 遺伝子 DNA の塩基配列を改変してアミノ酸配列を 変える手法は遺伝子工学的手法之呼ばれ, 特定のアミノ 酸残基を所望のアミノ酸残基に置換するための有用な手 段である. 1990 年以降大きく発展し, 生体のタンパク質 の構成ユニットである 20 種類のアミノ酸だけではなく, 重原子, 蛍光基, クロスリンカーなどの官能基を含むア ミノ酸 (非天然型アミノ酸) を, タンパク質の標的部位 に導入することも可能になってきた ${ }^{(1,2)}$. 一方, 有機化合 物を化学合成する手法む大きく発展し, 自然界がつくり 出す分子量が 1,000 以下の有機化合物の多くは化学合成 できる時代となった。
このような状況のもとで，これまでにない機能をもつ 分子を創製するためには，遺伝子工学と有機合成化学を 組み合わせるアプローチが有効なのではあるまいか。最 近筆者らは，遺伝子工学的手法を用いて組み込んだ非天 然型アミノ酸残基を反応点としてパラジウム触媒反応を 行ない，活性を損なわずに炭素一炭素結合を導入するこ とに成功した ${ }^{(3,4)}$. これは，100 残基以上のタンパク質を 基質にして遷移金属触媒反応を行なった，世界最初の例 である.

炭素-炭素結合は有機化合物の基本骨格であり，いか に炭素-炭素結合反応を行なうかが有機合成の鍵となる。 したがって, 任意の分子構造をタンパク質上に構筑しよ うとするならば，タンパク質上で炭素-炭素結合を形成 させる技術が必要であるが，そのためには穏和な条件 


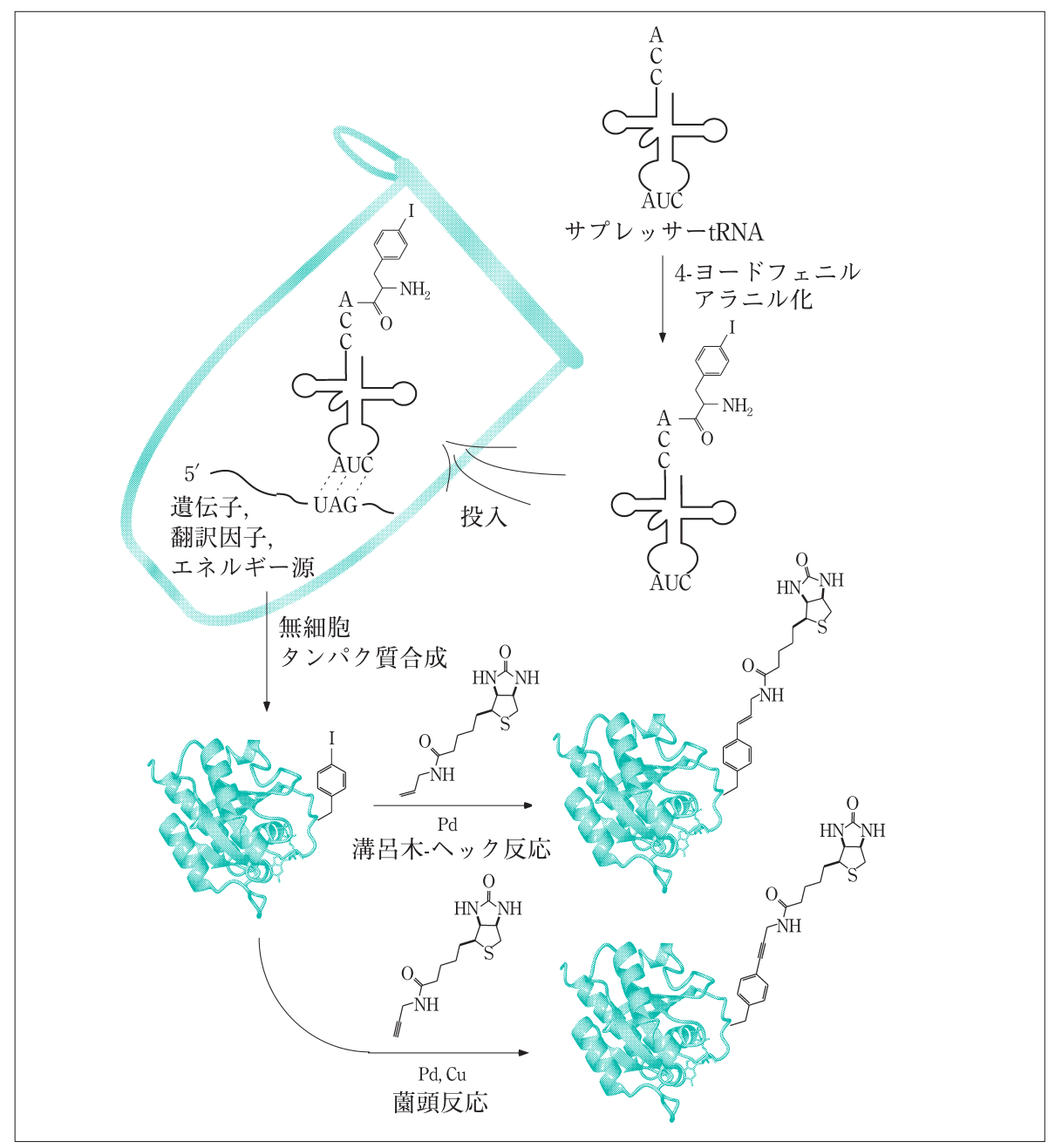

図 1 ロパラジウム触媒反応を用い て H-Ras タンパク質に炭素-炭素 結合を導入したスキーム
下，広範な基質で炭素-炭素結合の形成を可能にする遷 移金属触媒反応を利用するのがよいと思われた，遷移金 属触媒反応の中でも，パラジウム触媒を用いたクロス カップリング反応は最もよく研究されていて, 八ロゲン 化アリルもしくはアリールを基質とし，アルケニル化あ るいはアルキニル化する反応は，それぞれ溝呂木-ヘッ ク反応, 䄇頭反応と呼ばれている。溝呂木一ヘック反応, 䕐頭反応とも, 含水溶媒中で反応の進行することが報告 されていたが，タンパク質を基質にした実施例はなかっ た．そこで筆者らは, タンパク質上のヨウ化アリール基 をパラジウム触媒反応の反応点として利用することを考 え，モデルタンパク質として用いたヒト由来 H-Ras 夕 ンパク質にヨウ化アリール基を含む非天然型アミノ酸で ある 4-ヨードフェニルアラニンを, 遺伝子工学的手法に より組み込むことを試みた。
実験は以下のような手順で行なった（図 1)。まず，ナ ンセンスコドン UAG を認識するようにアンチコドンを 改変したサプレッサー tRNA に, 酵素を用いて4-ヨー ドフェニルアラニンを結合させた ${ }^{(5)}$. 次に, 4-ヨードフェ ニルアラニル化したサプレッサー tRNA を, 標的部位の アミノ酸残基に対応するコドンをナンセンスコドン UAG に改変した H-Ras タンパク質の遺伝子 DNA とと もに，大腸菌の翻訳因子抽出液を含む無細胞タンパク質 合成系に投入した。 UAG コドンはサプレッサー tRNA 以外の tRNA に認識されないので，4-ヨードフェニルア ラニン以外のアミノ酸は取り込まれない. 結果として, 標的部位に 4-ヨードフェニルアラニン残基をもつ HRas タンパク質を得ることができた(5).

わずかなエネルギーで安定化されているタンパク質の 立体構造は，生理的条件を外れると容易に変性する。ま 
た，タンパク質は遷移金属イオン存在下，酸化や非特異 的修飾などを受けやすいことが予想された。 そこで，基 質タンパク質を安定に保つために, タンパク質を安定化 させる効果をむつ塩化ナトリウム, グリセロール, 界面 活性剤などを反応系に添加したところ，これらだけでは 不十分であり, H-Ras タンパク質の分解・沈殿に加え, 基質のビニル基が非特異的にアミノ酸残基と反応する副 反応が認められた。 そこで, さらに条件検討を行なった ところ, ジメチルスルホキシドを加えることで H-Ras タンパク質の分解が抑えられ，また塩化マグネシウムの 添加により副反応や沈殿の形成が抑制されることがわ かった. マグネシウムイオンは, 遷移金属イオンがシス テイン残基やメチオニン残基の硫黄原子へ配位するのを 競合的に防ぐと推測される(4). さらに，パラジウム触媒 反応の前後で, H-Ras タンパク質の活性が保持されてい ることも確認した ${ }^{(3)}$. これらの結果は, パラジウム触媒 反応がタンパク質を変性させない温和な条件で行なわれ ることを示唆している。

H-Ras 改変体を基質として温和な条件下（室温以下， pH 8 前後), 溝呂木一ヘック反応および䕐頭反応を行な い，H-Ras タンパク質をビオチンで修飾した．タンパク 質上で進行するパラジウム触媒反応は, 反応点周辺のア ミノ酸残基による電荷や立体障害の影響を受けており, ペプチドをモデル基質としたパラジウム触媒反応と反応 条件や反応産物が異なっていた。 たとえば, ジメチルス ルホキシドと塩化マグネシウムは, タンパク質の変性を 抑制しただけでなく，タンパク質上でパラジウム触媒反 応を進行させるために必要であったが，ペプチドをモデ ル基質としたパラジウム触媒反応には必須でなかった。

ジメチルスルホキシドは可逆的にタンパク質の三次構造 を緩めて立体障害を軽減させ，2 価のマグネシウムイオ ンは負電荷をもつパラジウム触媒の配位子とタンパク質 間の静電反発を緩和すると考えられる(4).

タンパク質を変性させない条件で行なった溝呂木一 ヘック反応の反応収率は, 質量分析より $2 \%$ と推定さ れ，28\% は脱ハロゲン化物であった ${ }^{(3)}$. 一方, 薗頭反応 の反応収率は $25 \%$ で，13\%の脱ハロゲン化物も検出され た(4). 脱ハロゲン化物はペプチドをモデル基質としたパ ラジウム触媒反応では検出されなかったことより, タン パク質上での静電的反発や立体障害によってパラジウム 触媒反応が途中で終了した結果できたと考えられる ${ }^{(3,4)}$.

今後, 溝呂木一ヘック反応、䄇頭反応に加え, 様々な遷
移金属反応が炭素-炭素結合をタンパク質上で形成させ るために用いられると思われる。 これまで, 有機合成化 学は低分子化合物を標的分子としてきたが，今後はタン パク質を構成要素とした材料・システムを志向した研究 が行なわれるようになるだろう。タンパク質は複雑で精 巧な生命現象の主役として働く分子であり, 生体システ ムは主にタンパク質によって担われている. タンパク質 の特性を生かすことで, 生体を高度に模倣し, さらに生 体を超えた機能をむつ材料・システム（たとえば, 人工 モーター, バイオセンサー, 薬剂伝達システムなど）が 構築されるようになるだろう.

1) L. Wang \& P. G. Schultz: Angew. Chem. Int. Ed. Engl., 44, 34 (2004).

2) D. Kiga et al. : Proc. Natl. Acad. Sci. USA, 99, 9715 (2002).

3) K. Kodama et al. : ChemBioChem, 7, 134 (2006).

4) K. Kodama et al. : ChemBioChem, 8, 232 (2007).

5) K. Kodama et al. : ChemBioChem, 7, 1577 (2006).

(児玉公一郎*1, 中山 洋*2, 福沢世傑*1, *1東京大学大 学院理学系研究科, $* 2$ 理化学研究所基幹研究所) 